\title{
A Post-Cold War Geography of Forced Migration in Kenya and Somalia*
}

\author{
Jennifer Hyndman \\ Arizona State University West \\ Drawing on recent research in the Horn of Africa, emerging patterns of managing forced migration in the post-Cold \\ War landscape are identified and analyzed. While camps continue to house refugees, the meaning and value of 'refugee' \\ have changed dramatically since the Cold War. Efforts to prevent people from crossing political borders to seek safety \\ are increasing, giving rise to a new set of safe spaces. These new spaces are expressions of a distinct geopolitical discourse \\ and take the names 'UN protected area', 'preventive zone', and 'safe haven'. Their significance as a challenge to \\ state-centric geopolitics both within conflict zones and as refugee camps is explored in the Kenya-Somalia context. Key \\ Words: refugees, migration, displacement, Africa.
}

$\mathbf{T}$ This article was spawned by three forays into humanitarianism. In Kenya, I worked for a non-governmental organization (NGO) in Walda refugee camp during a period when its population was growing exponentially due to fighting in the Sidamo region of Ethiopia. In Somalia, I was employed by a United Nations agency as a field officer in Bardera, a town in the southern part of the country not far from the Kenya-Somalia border. Finally, I returned to Kenya as a researcher based primarily at three refugee camps on the other side of this same border. I began mapping the organization of humanitarian aid, interviewing its recipients and providers, and questioning its practices. Each of these experiences moved me to query the practices of those administering humanitarian locations and to theorize mobility for people 'out of place'-those uprooted from their homes due to fighting, famine, and fear.

My experience in Somalia, combined with my reading of post-structuralist accounts in geopolitics, as well as feminist and postcolonial theory, led me to believe that within humanitarian circles the assumed primacy of the nation-state was problematic. The relative fiction of the Somalian state became clear. Except for its role as a politicized venue for pan-Somali nationalism and as an interlocutor in agreements on military alliance and aid to Somalia, it was a country precariously sewn together. Not only was its governance historically a regional composite of a different scale (Stevenson 1993), but its borders were edges design(at)ed by colonial powers in the nineteenth century. These political borders were defended by colonial authorities in Kenya against the wishes and struggles of Somalis both inside and outside Kenya, and contested by Somali people during the Ogaden War (Hyndman 1997). Borders are forged through cartographies of struggle (Shapiro 1996), and so are refugees whose identities are based on border crossings.

States, borders, and refugees belong to a discourse of conventional geopolitics. Refugees, in the modern sense, are a creation of international law during this century. While refugees have by no means disappeared, the international refugee regime shows signs of giving way to more 'complex humanitarian emergencies'-distinct modes of multilateral response to human displacement. Conventional geopolitics and neorealist international relations have been carefully and convincingly countered by critical, poststructuralist, feminist, and Foucauldian commentators of international relations and political geography (Doty 1996; Ó Tuathail 1996b; Shapiro 1996; Murphy Erfani 1998). My aim in this paper is to add a geographical dimension to this work by grounding my analysis in the

"I would like to thank those who funded the research on which this paper is based: the Social Science and Humanities Research Council of Canada, the International Development Research Centre, and the gender unit of York University's Centre for Refugee Studies. Comments by Nadine Schumm:n and two anonymous teviewers were invaluable.

Professional Geographer, 51(1) 1999, pages 104-114 Copyright 1999 by Association of American Geographers. Initial submission, December 1997: revised submission, June 1998; final acceptance, July 1998 Published by Blackwell Publishers, 350 Main Street, Malden, MA 02148, and 108 Cowley Road, Oxford, OX4 1JF, UK 
arguably 'new' spaces and discourses emerging within humanitarian circles since the early 1990s.

\section{A Background Note}

Research focusing on operations of the United Nations High Commissioner for Refugees (UNHCR) provides the basis for this paper. UNHCR orchestrates responses to what are most often called 'humanitarian emergencies', crises of human displacement within and across political borders. The agency's mandate is to provide protection and assistance to involuntary migrants, and to seek permanent solutions to their displacement. During 1994-1995, I conducted an ethnography of UNHCR at three sites and scales of its operations: Geneva, Switzerland and Nairobi and Dadaab, Kenya. From the organization's headquarters in Geneva, directives are disseminated and information and field reports flow. Based on experience working with a non-governmental organization (NGO) in Kenya and UNHCR in Somalia, sites in Nairobi and Dadaab, a small town near the KenyaSomalia border, were selected for the study of this geographically-distributed UN agency. The sites represent three distinct levels of authority within a highly hierarchical organization. In the discussion which follows, UNHCR operations at several sites and scales provide background for a finer analysis of 'safe spaces' in Somalia and Kenya. Accordingly, recent decisions and actions taken by UNHCR serve as a departure point.

\section{Geography Matters}

Within the discipline of geography, a number of scholars have published research pertaining to refugee displacement. Not surprisingly, much of this body of work relates to refugees in the Horn of Africa where forced migration has been widespread and significant in scale (Rogge 1985; Kuhlman 1990; Black and Robinson 1993; Rogge 1993; Kuhlman 1994; Bascom 1996). Within the social sciences more generally, increasing attention has been paid to issues of displacement and migration. Analyses of displacement, diaspora, and identity in the context of people's movement across the globe have multiplied, particularly within cultural studies (Appadurai 1991; Basch et al. 1994; Bhabha
1994; Grewal and Kaplan 1994; Nixon 1994; Malkki 1995; Appadurai 1996; Kaplan 1996). While political geographers and others have critically analyzed geopolitics (Ó Tuathail 1996a, 1996b; Shapiro 1996; Tesfahuney 1998) and exposed the contingency of their representations, theoretical approaches that link discursive and political analyses of displacement in geography remain undeveloped. Critical appraisal of the power relations within and beyond the boundaries of major organizations that manage migration is also conspicuously absent. Both anthropologists and geographers have made the call to 'study up', to analyze and theorize institutions, organizations, and other power brokers that govern human relations rather than to study the governed themselves (Abu-Lughod 1991; Pred and Watts 1992). This approach has been employed in relation to the United Nations High Commissioner for Refugees (UNHCR).

Within the discipline, existing analyses of human displacement tend to be couched within a regional geography. While such an approach provides vital context, it risks neglecting links between particular places and the practices of international humanitarian organizations, like UNHCR, which operate across world regions. Accordingly, my argument turns on the connections between forced migration in one location and the increasingly transnational relations of power that shape the development and deployment of safe spaces in other locations of mass displacement. I aim to bridge some of the distance between cultural and political theories of displacement and the corporeal condition of human displacement. The refugee camps of Kenya and the construction of a preventive zone in Somalia represent related but distinct geographies of forced migration.

\section{A Geography of Refugee Definitions}

Refugees are perhaps the most obvious subjects of geographical inquiry. Forced to move from their homes to another country, they embody a visceral human geography of dislocation. The involuntary migration of bodies across space is, however, neither passive nor abstract. International responses to human displacement in the 1990s have become increasingly politicized and emphasize "managing migration." Who counts as a refugee varies across world regions, but most definitions depend on crossing an international 
border. The 1951 Convention Relating to the Status of Refugees includes anyone who has sought asylum

... as a result of events occurring before 1 January 1951 and owing to well-founded fear of being persecuted for reasons of race, religion, nationality, membership of a particular social group or political opinion. . ." - excerpt from Note 27, Article $1(\mathrm{~A})(1)$ of the Convention.

In crossing a political border, refugees trade the entitlements of citizenship in their own country for safety on terms decided by host governments and humanitarian agencies. Strategies to assist displaced people in refugee camps and safe havens constitute a principal focus of this work.

International migration has increasingly become a pressing subject for geographers, as people move across borders on an unprecedented scale for economic, political, social, and cultural reasons. No geographical region is immune to the consequences of wars which produce refugees; their numbers and concentration constitute a barometer of instability and conflict (Winter 1993). Refugees are also an expression of geographical change and conflict over time. From its conception in 1951, the Convention clearly demarcated spatial and historical limits. It was designed to apply to refugees in Europe displaced by events that occurred prior to 1951 . In 1967, the geographically-circumscribed and temporally restricted European definition of refugee, as outlined in the Convention, was amended in a new protocol to include all world regions and those displaced after 1951. The definition itself remained the same, however, generating a significant gap between the Eurocentric designation of 'refugee' and the drastically different conditions of post-colonial forced migration outside of Europe.

The Convention definition is a strategic conceptualization shaped by Eurocentric concerns after World War II (Hathaway 1991). Substantively, its emphasis on persecution-based on civil and political status as grounds for refugee status-expresses the particular ideological debates of post-WWII European tensions, in particular the perceived threats of communism and fascism in the wake of the Holocaust. In highlighting civil and political rights, the Convention has had the effect of minimizing the importance of social, economic, and cultural rights, and displacement related more to con- tests of colonial power and civil war than individual persecution. These features of the Convention-its original European geographical focus and emphasis on civil and political rights - have generated an uneven geography of refugee asylum which today is the subject of contentious debate and increasing political investment

In 1969, the Organization of African Unity $(\mathrm{OAU})$ announced a new regional convention which extended the definition of refugee, as outlined in the Convention and amended by the Protocol. The OAU Convention Governing the Specific Aspects of Refugee Problems in Africa not only broadened but also reformulated the definition of refugee, so that "the term refugee shall also apply to every person who, owing to external aggression, occupation, foreign domination or events seriously disturbing public order ..." seeks asylum across an international border (Article 1.2, OAU Convention). Slowly, the definition of refugee changed to incorporate political geographies other than those of Europe, albeit at regional scales.

Cold War tensions framed the Convention definition of refugee, in large part. Refugees during this period of communist-capitalist rivalry became more geographically widespread as each superpower sponsored proxies in the periphery to extend political influence and to control strategic locations. Refugees embodied significant political value during the Cold War, as the US and USSR each claimed them as evidence of its superiority. In the post-Cold War landscape of the $1990 \mathrm{~s}$, their value and meaning have changed dramatically. Today, the majority of refugees emerge from regions other than Europe. While human legacies of Cold War posturing remain, refugees in the 1990 s are more likely to flee civil wars than international ones (Rogers and Copeland 1993). The location, meaning, and measures employed to assist refugees have all been recast, and with this reconfiguration, new kinds of safe areas and an attendant discourse have emerged.

The cases of Kenya and Somalia are instructive. Preventive zones in Somalia represent one kind of safe area within a country still at war. Refugee camps in Kenya are an expression of the more conventional treatment of displacement. Together, they comprise a geo-political continuum of humanitarian response in a post-Cold War landscape. The zones and camps are concrete 
spaces embedded in a strategic and geographical discourse of rights and 'preventive protection' (UNHCR 1995). By analyzing the conditions of displacement for Somalis in Kenya and Somalia, as well as the meanings attached to these distinct spaces, implications for similar cartographies of power in other areas affected by forced migration are developed.

\section{New Spaces, New Strategies}

The end of the Cold War raised hopes of fewer conflicts and greater peace on a global scale. These hopes have, for the most part, been dashed by the rise of ethnic nationalism, civil conflict, and secessionist claims. Since the end of the Cold War, there has been a respatialization of responses to crises of human displacement. The major players in the international refugee regime, namely donor governments of the North, are shifting their emphasis from 'the right to leave' one's country in the face of persecution or violence to the 'the right to remain' (UNHCR 1995). Displaced people are encouraged to stay within their countries of origin by providing assistance to them there, rather than having them seek protection through asylum across an international border. Because of the inherent risks associated with this strategy, Hathaway (1994) has called the right to remain, the "right to be toast." Some policy analysts say the concept violates the right to leave one's country outlined in the UN Declaration of $\mathrm{Hu}$ man Rights. Mass killings in the so-called 'safe haven' of Srebrenica in July 1995 demonstrate the extent to which this strategy can go seriously awry.

This shift in discourse from 'the right to leave' and 'the right to seek asylum' to 'the right to remain' gives rise to distinctive safe areas. More traditional safe spaces, namely refugee camps, are also relevant to this post-Cold War shift. While camps are intended as a temporary solution for refugees seeking safety and basic material assistance, they are becoming increasingly permanent. International funding to assist displaced people in both kinds of safe spacesprotected areas and camps - is relatively plentiful, especially if they can be helped 'at home' or nearby. 'Preventive protection' designates a new set of safe spaces and management practices for forcibly displaced people. It is part of a declared "paradigm shift" in refugee policy which oc- curred in the early 1990s (Frelick 1993). The international humanitarian intervention in Northern Iraq to assist displaced Kurds inside the country in 1991 is said to mark this turning point. 'Safe havens' for Iraqi Kurds, 'zones of tranquillity' for returning Afghan refugees, 'open relief centers' for would-be Sri Lankan refugees, and 'safe corridors' to Muslim enclaves in Bosnia are all examples of this current trend and expressions of a distinct post-Cold War discourse.

Preventive protection is evident in the 'geopolicing' of migration (Tesfahuney 1998). Measures to control border crossings into most industrialized countries in North America and Europe include airline carrier sanctions, increased demand for identity documents, finger printing of refugees, fortification of borders with fences and increased personnel, video surveillance and monitoring, new visa requirements for nationals of so-called 'Third World' countries, and revised-more exclusive-notions of citizenship. Tesfahuney notes that these measures have the effect of racializing and criminalizing the migrant question.

Recent history in Somalia provides a telling example of 'preventive protection' and its geographical implications. In Southern Somalia, adjacent to the Kenyan border, UNHCR created a 'preventive zone' along the Kenyan border. Its purpose was to slow the flow of potential refugees into Kenya and to encourage Somali refugees in Kenyan camps to return home. The use of this circumscribed safe space within a conflict area is part of an emerging geography of displacement discussed later in the paper.

\section{UNHCR: One Organization Geographically-Distributed}

The UNHCR operates today on a scale unimaginable at its conception. It is responsible for more refugees today than any other period since World War II (Holborn 1975; UNHCR 1993). The Office of UNHCR has a mandate to assist and protect refugees and to arrange permanent solutions to their displacement. This mandate has evolved over time and space: once limited to assisting refugees in Europe displaced by the events of WWII, UNHCR now works worldwide to assist not only refugees but other displaced groups. In the post-Cold War period, the organization has moved from operating exclusively in safe countries of asylum to operating 
in war zones. Where it once cooperated with development agencies, it now collaborates with peace keepers in places like Northern Iraq, BosniaHercegovina, and Somalia. In the first four decades of its operations, the United Nations launched 13 peacekeeping missions; between 1988 and 1995 it authorized twenty-five (UNHCR 1995).

There is an increasing reliance by individual states on multilateral agencies, such as UNHCR, to deal with humanitarian crises (Hyndman 1996). UNHCR has moved from interpreting legal obligations and encouraging humanitarian response on the part of member states to managing crises of displacement on the ground.

Twenty years ago, the Office of the United Nations High Commissioner for Refugees consisted of some lawyers in Geneva revising and amending the international conventions concerning refugees. Now it is a global rapid-reaction force capable of putting fifty thousand tents into an airfield anywhere within twenty-four hours, or feeding a million refugees in Zaire... The United Nations has become the West's mercy mission to the flotsam of failed states left behind by the ebb tide of empire. - Michael Ignatieff (1995:7)

Since 1990, UNHCR's role has changed dramatically. In 1990, the agency had a budget of $\$ 544$ million and a staff of 2,400 . By 1996 , the budget had grown to about $\$ 1.3$ billion and the staff to 5,000 (Frelick 1997). Recent changes within UNHCR are expressions of transformations on a broader scale, as the post-Cold War order is fashioned. The UNHCR itself says that the organization "has been transformed from a refugee organization into a more broadly-based humanitarian agency" (UNHCR 1995, 48). The agency's focus has broadened to meet the exigencies of current political crises, yet the bases for such change are not clearly defined:

The world's most powerful states and the United Nations itself have been placed in a considerable dilemma by the rash of internal conflicts and humanitarian emergencies since the demise of the bipolar state system. While the old rules of the game have evidently changed, the international community has found it extremely difficult to articulate a coherent set of principles and practices which are geared to contemporary circumstances (UNHCR 1995, 115).

UNHCR's operations in the Horn of Africa represent a particular case of this shifting geo- political culture emerging after the Cold War. They signal the increasing significance of multilateral channels of humanitarian intervention.

Permanent solutions to refugee displacement are, I contend, decreasing now that the Cold War is over. UNHCR espouses three such 'durable solutions' to refugee displacement. Voluntary repatriation to one's country of origin is the preferred option and the most sensible recourse, if it is available. If not, UNHCR promulgates local integration into the country and community of asylum. Finally, a select number of refugees - less than one percent of the total-may be resettled abroad. Failing these permanent solutions, many refugees end up in technically temporary camps governed by UNHCR. Increasingly, camps are becoming longer term responses to unresolved conditions of human displacement. In the case of Somali refugees in Kenya, voluntary repatriation is out of the question for many, as fighting continues in parts of Somalia. Local integration is precluded by the Kenyan government which doesn't want refugees living in the country to compete with Kenyans for the few jobs available. Finally, opportunities for resettlement abroad represent the sole hope for many refugees in Kenya who wait years for the unlikely event that the 'lottery' will rule in their favor.

Popular support for refugee resettlement, i.e. immigration, is at a historic low. In North America, changes in public policy have led to a decline in opportunities for Convention refugees to immigrate. Refugee resettlement numbers in both the US and Canada have fallen precipitously in recent years, signaling increased reluctance to host refugees in North America on a permanent basis (see Table 1). As resettlement targets decline, the allotment of places for African refugees is already disproportionately small. African refugees comprise $36 \%$ of the world refugee population, yet in 1995-1996, the US allotted just $6.3 \%$ of its resettlement openings to African refugees.

Screening activities for refugee resettlement in Africa attest to a remarkable geographical concentration. In the US case, most screening activities for Sub-Saharan Africa are based in Nairobi where the Immigration and Naturalization Service (INS) has its only office in that region. This concentration of resettlement services is somewhat surprising, given that refugees are required to remain in the rural camps. Only 
Table 1 Annual Resettlement Ceilings for Government-Sponsored Refugees

\begin{tabular}{lrrrrr}
\hline & $1992 / 93$ & $1993 / 94$ & $1994 / 95$ & $1995 / 96$ & $1996 / 97$ \\
\hline USA & 142,000 & 121,000 & 110,000 & 90,000 & 78,000 \\
Canada & 13,000 & 11,000 & 7,300 & 7,300 & 7,300 \\
\hline
\end{tabular}

Sources: U.S. Department of State, Department of Justice, \& Department of Health \& Human Services. "Report to the Congress on Proposed Refugee Admissions for Fiscal Year 1996", July 1995. Pre publication copy; "Report to the Congress on Proposed Refugee Admissions for Fiscal Year 1995", September 1994; most recent numbers are taken from the State Department web site at http://www.state.gov/Mww/ global/prm/FY97refugees.html. Canadian totals are announced every November 1st; they come from Citizenship and Immigration Canada and were confirmed for the purpose of this table by the Immigrant Services Society of $B . C$

the US government contracts people to go to the camps to conduct preliminary interviews with refugees. Not surprisingly, more than 100,000 refugees in Kenya are estimated to live in urban areas without permission.

\section{Situating Displacement: The Case of Somalia and Kenya}

Africa hosts more displaced persons than any other continental region. At the end of 1995 , UNHCR counted 27.4 million refugees and other 'persons of concern'. More than 11 million of these lived in Africa alone. Kenya is in the unenviable geographical position of sharing borders with no fewer than five other nations, all of which-with perhaps the exception of Tanzania-have generated sufficient internal conflict to produce asylum seekers in Kenya. It should be noted, however, that refugees in this region are not specific to the post-Cold $W_{\text {ar }}$ period (Hyndman 1997). Some of the major refugee flows in the post-1945 era were induced by superpower rivalries, combined with "past and present economic and geopolitical orders of colonialism, global inequality and Western hegemony" (Tesfahuney 1998, 500). The Ogaden war of the 1970s in which Somalia launched an offensive against Ethiopia for the Ogaden region provides a good example. Regional geopolitics were imbricated in Cold War tensions, as superpowers backed opposite sides during the conflict-one which generated hundreds of thousands of refugees. A more geographicallycircumscribed example of refugees in Kenya stems from the ethnic cleansing policies of Ida Amin in Uganda during the 1970s. Considerable evidence has shown that migratory movements often arise from the existence of prior links beween sending and receiving countries based on relations of colonization, political influence, trade and investment, or cultural ties (Castles and Miller 1993; Sassen 1996).

During the peak of human displacement after the Cold War in 1992, however, there were some 420,000 refugees in Kenyan refugee camps (Immigration and Refugee Service of America 1996). The vast majority of these were from Somalia. Somalian President Siad Barre was ousted from power in January 1991. By 1992, civil conflict had become widespread and had induced famine in several parts of the country. Images of malnourished Somalians appeared on televisions worldwide, winning public sympathy and government donations to fund humanitarian efforts in both Somalia and Kenya. A series of refugee camps and temporary border sites were established in Kenya to accommodate Somalians as they crossed the border in desperate physical condition. Mortality rates soared in these ill-prepared makeshift camps until water quality, sanitation conditions, and food supplies could be stabilized. Deaths were counted by the number of shrouds-simple pieces of white cloth distributed on demand-and by the number of bodies discernible in graveyards located at the perimeter of the camps. Working in one of the Kenyan refugee camps at that time, I witnessed the costs and corporeality of displacement on a human scale.

The 'encampment' of refugees raises an interesting question: why were these refugees required to live in camps, rather than in the cities where they might be able to find work, as many before them had? Part of the answer lies in the number of refugees the Government in Kenya was coping with, and much of the explanation lies in the source country of the majority of refugees (see Hyndman and Nylund 1998). Of Somali refugees admitted to Kenya after 1991, all were granted temporary and spatially circumscribed asylum in camps as prima facie refugees, an issue to which I will return later in the paper. The geopolitics of refugee containment in the absence of the 'preventive protection' option (in Somalia) were certainly clear in the government decision to locate refugees in camps.

By the end of 1996, Kenya hosted roughly 185,000 refugees, of which 150,000 were from Somalia. ${ }^{1}$ The UNHCR was the agency responsible for coordinating responses to this 
wave of forced migration on both sides of the Kenya-Somalia border. In camps and border sites, non-governmental organizations (NGOs) were hired as 'implementing partners' to deliver health services, distribute food, and provide ample water for the refugee population. On the other side of the border, efforts to slow the flow of refugees into Kenya from Somalia and to repatriate Somali refugees began, also under the auspices of UNHCR.

\section{Preventive Protection: The Cross-Border Operation}

The Cross-Border Operation was launched in Southern Somalia late in 1992. Four UNHCR 'outposts' were established at various locations roughly one hundred miles from the KenyaSomalia border, as part of the Cross-Border Operation. The distance between the border and the outposts situated inland along the Juba River circumscribed a 'preventive zone'. In 1993, I worked in Bardera, Somalia on the Cross-Border Operation for UNHCR. This relief effort consisted of community-based projects to rehabilitate a war-torn area and of refugee repatriation activities to bring Somalians in Kenyan camps home. UNHCR's Cross-Border Operation was a distinct expression of the post-Cold War geo-political landscape. At the request of the UN Secretary-General, UNHCR initiated the Cross-Border Operation inside Somalia in order to stem the flow of refugees from Somalia to Kenya and to entice those refugees already in Kenya to come home. Perhaps the most vivid testimony of prevention was the passing of $\mathrm{UN}$ Security Council Resolution 794 which authorized a Unified 'Task Force (UNITAF) of thousands of peacekeeping troops to enter Somalia so that relief supplies could be safely delivered. 'Operation Restore Hope', as the mission was called, was the first peacekeeping operation that intervened in a sovereign member state when that state did not present a military threat to its neighbors (Makinda 1993). This move challenged the sacrosanct sovereignty of states by entering a country in the absence of an external threat. Somalian society was portrayed as an anarchy imploding on itself, and humanitarian need was considered grave enough to warrant multilateral intervention (Shohat and Stam 1994). United Nations membership is comprised of states, however, and this contravention of state sovereignty-not unlike the UN-led effort to assist Kurds in Northern Iraq in the fall of 1991 - introduces a distinct tension in international geopolitics. State autonomy and respect is expected by government signatories to the UN, but not at other states' expense. The Somalia intervention demonstrates that state sovereignty is now qualified in a way that it was not before 1991.

Late in 1992, Kenyan President Moi had announced that refugees would be sent back to Somalia immediately. Without President Moi's support, UNHCR could not operate on the same scale within Kenya, and so sustained efforts to fund an alternative 'preventive' path ensued. Thus, the preventive zone had a humanitarian purpose, but was shaped, in large part, by political exigency. Prevention, as a humanitarian measure, also has financial implications and therefore political significance. As Cold War tensions dissipate, governments in many industrialized countries have moved to curb social spending of all kinds (Hayes 1994). Under the umbrella of New Right politics or the rubric of neo-liberalism and its prescriptive fiscal restraint, individual states are reconsidering the form and function of their welfare states. Refugees are seen to lean heavily on social spending, so the impetus to accept refugees for resettlement in these countries is low. There is ample evidence that states are keen to avoid their legal obligations to refugees where multilateral agencies like UNHCR can step in and assist on an ad boc basis. Funding for UNHCR's humanitarian activities, for example, have exceeded US\$1 billion since 1992 (UNHCR 1993). In another way, prevention is tactical: if human displacement across borders can be prevented then so too can future obligation to would-be refugees. This is a cynical view, but not an unwarranted one. The establishment of 'safe corridors' in the case of Bosnia provides one example: "We must also funnel humanitarian assistance to hundreds of thousands more who are besieged inside Bosnia, so that they do not become the next wave of refugees. It will require the opening of safe corridors to accomplish this goal" (U.S. Secretary of State, Lawrence Eagleburger, August 26, 1992, cited in Frelick 1993, 9). Prevention can prevail over concerns for refugee protection.

By June 1993, some 30,000 Somalian refugees had returned home from Kenya, but the vast majority remained in the camps (UNHCR 1993). 
Confrontation between $\mathrm{UN}$ and Aideed forces in Mogadishu damaged the UN reputation of neutrality and hastened the peacekeepers' departure. By the end of March 1995, almost all peacekeepers had left Somalia, with more than 150,000 Somali refugees still in Kenyan camps. While UNHCR designated and mapped the preventive zone as a safe space, the majority of Somali refugees in Kenya stayed put. As in Srebrenica, there was a crucial difference between the intentional mapping of the UN intent and the movement of people on the ground based on different perceptions of safety.

\section{Managing the Camps: A Geography of Containment}

Localized strategies of refugee camp management are an expression of the shifting geopolitical terrain on an international scale. The Kenyan Government has not granted Convention refugee status since 1991. It insists that all prima facie refugees live in camps, not in cities or towns. Prima facie status means that refugees are not allowed to leave the camps nor can they seek employment, though many of them do so in unofficial ways. Basic health, shelter, and nutritional needs are met by UNHCR and other international relief agencies through what is often called 'care and maintenance' operations (UNHCR 1994). Just as safe havens and UNdesignated zones are predicated on a discourse of 'preventive protection' and 'the right to remain', so too are refugee camp operations steeped in the therapeutic language of 'care and maintenance.'

Prima facie status is a group designation that has been ascribed to Somalian, Sudanese, and Ethiopian refugees in Kenya when they cross the border to escape danger recognized by UNHCR in their home countries. Unlike the systematic, individual determination of Convention status which affords a much broader range of rights and mobility entitlements, it is also an $a d$ boc status. The ad boc application of prima facie refugee status when deemed necessary may sound fickle and functionalist, but this is precisely point. Granting refugees prima facie rather than Convention status is a de facto segregation measure, whether intended as such or not.

In Kenya, all prima facie refugees must reside in camps, therefore the refugee 'problem' is contained in remote border locations, literally and figuratively on the 'edges of the nation.' From November 1994 to February 1995, I conducted research in three of these camps-Ifo, Dagahaley, and Hagadera-near the town of Dadaab in Northeast Kenya (see Fig. 1). When I first stayed in Dadaab in 1992, it was nothing more than a dusty village with fewer than five telephones. By 1995, it hosted new permanent buildings constructed by UNHCR, had a booming economy due to humanitarian-based jobs and inputs, and was coping with exponential population growth. Sustained efforts to repatriate Somalian refugees or remove them from camps located near the Kenyan coast to the Dadaab camps were on-going at that time because the Government insisted that all coastal refugee camps be closed.

These temporary cities embody sophisticated networks of unofficial trade, movement, and livelihood (Hyndman 1995). Daily flights and buses from Nairobi move goods and people through this emerging Dadaab hub on an unprecedented scale. Informal economies have arisen in which refugees work 'under the table' for locals and for the Kenyan police who guard the camps. Such relations of employment are highly gendered and unequal, as refugee women and girls are most often the ones to work as maids and prostitutes for Kenyan men. A new economy of trade in documentation has grown up around the food distribution system and refugees restricted mobility in the camps. Ration cards are bought and sold; Kenyan identity cards are forged and traded, so that refugees may travel more freely. The contemporary history of ethnic discrimination against Somalis by the Kenyan Government and other cultural groups, however, also informs the politics of refugee mobility in this region (Hyndman 1997).

Many refugees have spent more than five years in the Kenyan camps, completely dependent on international aid. This unusual configuration of local reliance on global goodwill is not sustainable, nor does it abide by existing human rights instruments. While the Kenyan Government stipulates the location of camps and refugee restriction to them, it is UNHCR that designates prima facie status. UNHCR recognizes that the "old rules of the game have evidently changed", but the use of prima facie status on such a significant scale and for sustained periods underscores how difficult it is "to articulate a coherent set of principles and practices 


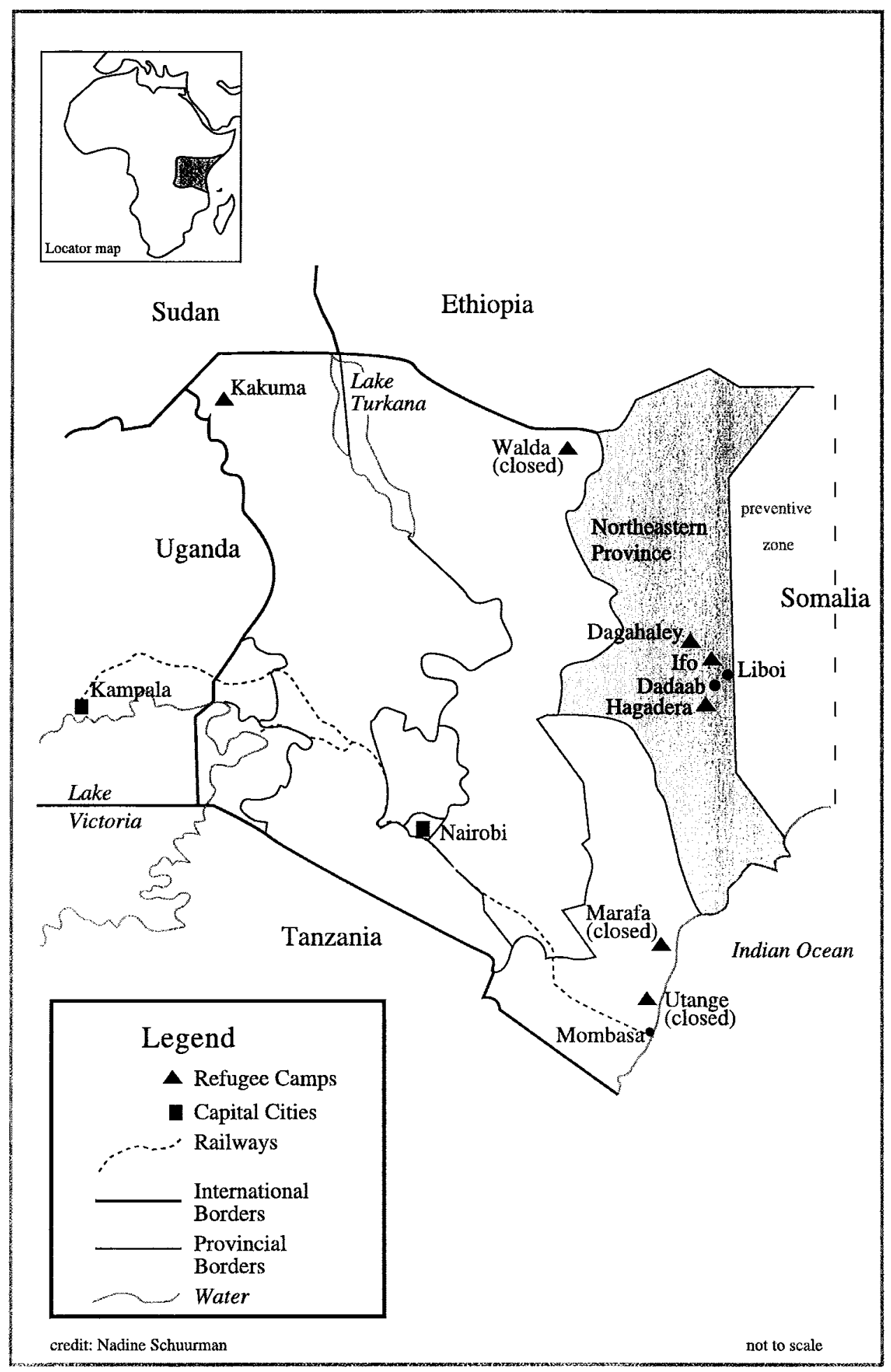

Figure 1: Refugee camps in Kenya. 
which are geared to contemporary circumstances" (UNHCR 1995, 115). Rather, in the absence of principles against which to measure such practice, a tacit strategy of spatial segregation has been implemented. Because of the limited protection and assistance prima facie status affords, it is an officially 'temporary' measure that is informally becoming entrenched as an $a d$ boc solution.

Just as the strategic value of refugees has decreased, so too has the desire to assist and adopt refugees. The use of prima facie refugee status will likely increase in the absence of local integration and resettlement opportunities for most refugees. As ad boc measures to manage and contain refugees in camps become ad boc solutions, evidence suggests that efforts to prevent the costs and legal obligations of asylum by employing safe spaces 'at home' will continue as the preferred geography of forced migration.

\section{Conclusions}

Preventive protection and safe havens are novel expressions of managing human displacement in a post-Cold War order. Camps remain a more conventional space for protecting prima facie refugees, but their temporary and ad boc status in the current geo-political context is questionable. Increasingly, preventive zones and UNprotected areas require soldiers to keep the peace and protect potential refugees in conflict zones. For those who manage to flee across a border, as in the case of Kenya, the designation of prima facie status signals placement in remote border camps. A palpable tension between humanitarian need and the political interests of states is evident.

Another tension has emerged between the sovereign state and the state under siege, in which civilians have been displaced. Since 1991, international multilateral interventions into countries at war have become commonplace. Preventing asylum across borders and, at the same time, protecting internally displaced people in safe areas has been a major impetus for UN missions to Iraq, Bosnia-Hercegovina, Rwanda, and Somalia. The geopolitical landscape of the post-Cold War order has proven markedly different from that which came before. Sovereignty is no longer sacrosanct; a new, if unstable, geography of forced migration has emerged.

\section{Note}

${ }^{1}$ To be fair, the Government of Kenya has generated considerable internal displacement in contrast to the hospitality it has shown refugees. Kenyans, many of them of Kikuyu ethnicity, have been forced to move due to political and ethnic violence dating back to 1991-1992 when 300,000 people were displaced and 1,500 were killed in Western Kenya. At the end of 1996, an estimated 100,000 people had been forced to leave their homes but remained within the country, while some 8,000 more were refugees in neighboring Ethiopia (Immigration and Refugee Services of America 1997).

\section{Literature Cited}

Abu-Lughod, Lila. 1991. Writing against culture. In Recapturing Anthropology, ed. R.G. Fox, 137-162. Sante Fe, NM: School for American Research.

Appadurai, Arjun. 1991. Global ethnoscapes. In Recapturing Anthropology, ed. R.G. Fox, 191-211. Sante $\mathrm{Fe}, \mathrm{NM}$ : School for American Research.

1996 Sovereignty without territoriality: Notes for a postnational geography. In Geograpby of Identity, ed. P. Yaeger, 40-58. Ann Arbor: University of Michigan.

Basch, Linda, Nina Glick Schiller, and Cristina Szanton Blanc. 1994 Nations Unbound: Transzational Projects, Postcolonial Predicaments, and Deterritorialized Nation-States. Langhorne, PA: Gordon and Breach.

Bascom, Johnathan. 1996. Long journey in place: Refugee women and social transformations in exile. Paper presented to the American Association of Geographers' annual conference, April 10, Charlotte, NC.

Bhabha, Homi. 1994. The Location of Culture. London/New York: Routledge.

Black, Richard, and Vaughan Robinson, eds. 1993. Geography and Refugees: Patterms and Processes of Cbange. London/New York: Belhaven Press.

Castles, Stephen, and Mark J. Miller. 1993. The Age of Migration: International Population Movements in the Modern World. New York: Guilford Press.

Doty, Roxanne Lynn. 1996. Imperial Encounters: The Politics of Representation in North-South Relations. Minneapolis: University of Minneapolis Press.

Frelick, Bill. 1993. Preventing refugee flows: Protection or peril. In World Refugee Survey, 1993. Washington, DC: US Committee for Refugees.

- 1997. Assistance without protection; Feed the hungry, clothe the naked, and watch them die. In World Refugec Survey, 1997. Washington DC: Immigration and Refugee Service of America.

Grewal, Inderpal, and Caren Kaplan. 1994. Introduction: Transnational feminist practices and questions of postmodernity. In Scattered Hegemonies: Postpnodernity and Transnational Feminist Practices, ed. I. 
Grewal and C. Kaplan, 1-33. Minneapolis: Minnesota University Press.

Harrell-Bond, Barbara. 1986. Imposing Aid: Emergency Assistance to Refugees. Oxford/New York/Nairobi: Oxford University Press.

Hathaway, James C. 1991. The Status of Refugee Law. Markham/Vancouver: Butterworths.

1994. Introduction to the law of refugee status.

Lecture presented at Centre for Refugee Studies, York University, Toronto, June 23.

Hayes, Michael. 1994. The New Right in Britain. London/Boulder: Pluto Press.

Holborn. Louise. 1975. Refugees: A Problem of On Time: The Work of UNHCR 1951-72. Metuchen, N]: Scarecrow Press.

Hyndman, Jennifer. 1995. Supra-citizen \& sub-citizen: Subjects at the border. Tessera 18: 78-89.

1996. International responses to human displacement: Neo-liberalism and post-Cold War geopolitics. Refuge 15, 3: 4-9.

- 1997. Border crossings. Antipode 29, 2: $149-76$

Hyndman, Jennifer, and Bo Viktor Nylund. 1998. UNHCR and The Status of Prima Facie Refugee Status in Kenya. International Foumal of Refugee Law 10:1 forthcoming.

Ignatieff, Michael. 1995. Alone with the SecretaryGeneral, The New Yorker August 14: 33-9.

Immigration and Refugee Service of America. 1996. World Refugee Survey, 1996. Washington, DC: US Committee for Refugees.

1997. World Refugee Survey, 1997. US Committee for Refugees.

Kaplan, Caren. 1996. Questions of Truvel: Pastmodern Disconrses of Displacement. Durham, NC: Duke University Press.

Kuhlman, Thomas, 1990. Burden or boom? Eritrean refugeer in the Sudan. London: Zed Books. 1994. Asylum or Aid? The Economic Integration of Etbiopian and Eritrean Refugees in the Sudan. Aldershot: Avebury Publications.

Makinda, Samuel M. 1993. Seeking Peace From Cbaos: Humanitarian Intervention in Somalia. Boulder/London: Lynne Rienner Publishers.

Malkki, Liisa H. 1992. National Geographic: The rooting of peoples and the territorialization of national identity among scholars and refugees. $\mathrm{Cul}$ tural Antbropology 7, 1:24-43.

1995. Refugees and exile: From "refugee stud ies" to the national order of things. Annual Review of Anthropology, 24: 495-523.

Murphy Erfani, Julie. 1998. Globalizing Tenochtitlán? Feminist geopolitics: Mexico City as borderland. In Border Space, ed. Kathy Staudt. Boulder, CO: Lynne Rienner Publishers, forthcoming.

Nixon, Rob. 1994. Refugees and homecomings: Bessie Head and the end of exile. In Travellers' Tales: Narratives of Home and Displacement, ed. G. Robertson et al., 114-28. New York/London: Routledge.
Ó Tìathail, Gearóid. 1996a. An anti-geo-political eye: Maggie O'Kane in Bosnia, 1992-93. Gender; Place and Culture 3, 2: 171-85.

1996b. Critical Geo-politics. Minneapolis: University of Minnesota Press.

Pred, Alan, and Michael Watts. 1992. Reworking Modemity. New Brunswick, NJ: Rutgers University Press.

Rogers, Rosemary, and Emily Copeland. 1993. Forred Migration: Policy Issues in the Post-Cold War World. Boston, MA: Tufts University.

Rogge, John. 1985. Too Many, Too Long: Sudan's Twenty-Year Refugee Dilemma. Totowa, NJ: Rowman and Allanheld.

1993 The Challenges of changing dimensions among the South's refugees: Illustrations from Somalia. International fournal of Refugee Law 5, 1: 12-30.

Sassen, Saskia. 1996. Losing control? Sovereignty in an age of globalization. New York: Columbia University Press.

Shapiro, Michael J. 1996. Violent Cartographies: Mapping Cultures of War. Minneapolis: University of Minnesota Press.

Shohat, Ella, amd Robert Stam. 1994. Untbinking Eurocentrism: Multiculturalism and the Media. New York/London: Routledge.

Stevenson, Jonathan. 1993. Hope restored in Somalia? Foreign Policy 91: 138-54.

Tèsfahuney, Mekonnen. 1998. Mobility, racism, and geopolitics. Political Geography 17, 5: 499-515.

United Nations High Commissioner for Refugees (UNHCR). 1993. The State of the World's Refugees: The Challenge of Protection. Toronto: Penguin.

1994. Country operations plan-Kenya, Nairobi, October.

1995. The State of the World's Refugees: In Searcb of Solutions. Oxford/New York: Oxford University Press.

U.S. Department of State, Department of Justice, and Department of Health and Human Services. 1994. Report to the Congress on proposed refugee admissions for fiscal year 1995, September.

1995. Report to the Congress on proposed refugee admissions for fiscal year 1996, July. Prepublication copy.

Winter, Roger. 1993. The year in review. World Refugee Survey, 1993. Washington, DC: US Committee for Refugees.

JENNIFER HYNDMAN is Assistant Professor of Geography at Arizona State University, West Campus, P.O. Box 37100, Phoenix, AZ 85069 7100 . Her research interests include refugee resettlement and immigration policy, feminist theories of migration and displacement, as well as gendered violence in conflict zones and refugee camps. 